and consequently determining the yield of the fishery in the three zones.

The investigation will be continued and a detailed report published later elsewhere.

Wilhelm Brandhorst

Technical Foreign Aid Program of

the Federal Republic of Germany,

German Embassy, Casilla 9949

Santiago de Chile. March 6.

${ }^{1}$ Gunther, E. R., Discovery Rep., 13, 107 (1936).

2 Steemann Nielsen, E., J. Mar. Res., 14, 374 (1955).

${ }^{3}$ Wooster, W. S., and Cromwell, T., Bull. Scripps Inst. Oceanogr.

7, 162 (1958). Brandhorst, W., J. Cons. Int. Explor. Mer, 24

16 (1958); Nature, 182, 679 (1958); J. Cons. Int. Explor. Mer

(in the press).

\section{Life-Span of Rat and Mouse Erythrocytes in the Rat-Mouse Chimera}

THE secondary disease observed in irradiated animals treated with foreign bone marrow is of general interest and importance. The basic question which remains unanswered is whether immunologically competent cells in the chimera originate from the donor, the host, or a combination of both. Erythrocyte life-span studies might be expected to throw light on whether this secondary reaction, in so far as it is reflected in red cell survival, is of host or of donor origin.

Nine $(C 57 \times 101) F_{1}$ female mice that survived 60 days after $900 \mathrm{r}$. of X-rays ( $L D 100 / 20$ days) and an injection of Sprague-Dawley rat bone marrow $\left(55 \times 10^{6}\right.$ nucleated cells/mouse) on day zero were transfused intravenously with $0.2 \mathrm{ml}$. of a 45 per cent suspension of chromium-51-labelled red blood cells in saline. Four mice were given labelled isologous erythrocytes and five were given labelled rat erythrocytes; blood was pooled from normal donors for each group. The activity of chromium-51 in circulating blood measured at $24 \mathrm{hr}$. was taken as 100 per cent, and measurements were made at intervals for 7 weeks. 25 days after the transfusion of labelled cells these animals had essentially 100 per cent rat erythrocytes by the mannitol test ${ }^{1}$.

The level of activity of chromium-51 is plotted against time in Fig. 1, and it can be seen that the

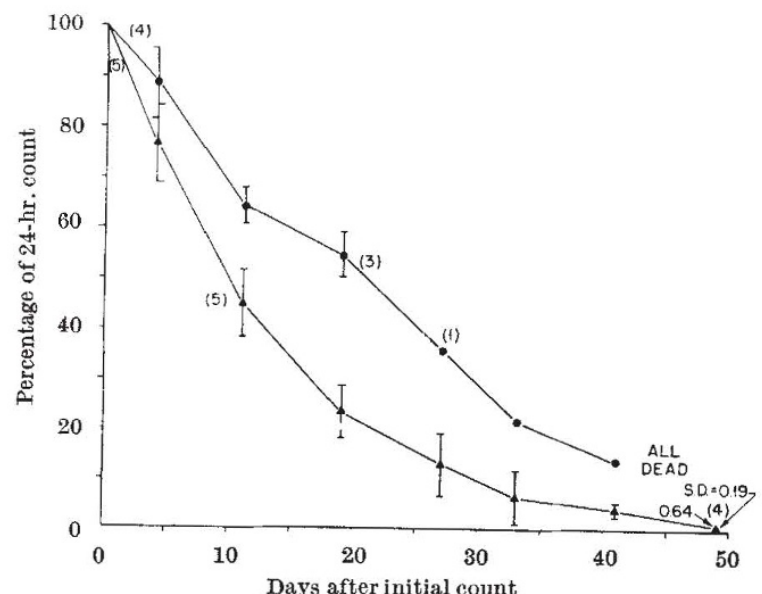

Fig. 1. Disappearance of chromium-51 activity from the circulating blood of rat-mouse chimeras transfused on day zero minus one with either mouse (upper curve) or rat (lower curve) labelled erythrocytes. Number of surviving animals in each group is shown in parentheses at three time points on the curves. Standard deviations are indicated by vertical bars at each point plotted rat cells disappeared more rapidly in the chimera than did the mouse cells. The latter followed a normal life-span curve for this strain. The curve for rat erythrocytes is intermediate between that for rat cells in the normal rat (maximum life span : 60 days) and that for rat cells in the normal mouse (maximum life span : 4 days) (Smith and Tohá²). It was found by Smith and Tohá ${ }^{2}$ that rat cells from a rat-mouse chimera survived in normal recipients like cells from a normal rat.

It is clear from these preliminary results that the long-term heterologous chimera, although 100 per cent of its circulating erythrocytes are of rat origin, provides an imperfect environment for rat red blood cells. On the other hand, the presence of active rat hæmatopoietic tissues in such a host does not influence the survival of transfused mouse erythrocytes. This study therefore provides no evidence of an active rat immune system. Whether the accelerated destruction of rat cells reflects a recovering host immune system, as is clearly indicated by the findings of Gengozian et $a l .^{3}$, or only the foreign biochemical and physiological environment of these heterologous cells cannot be answered by these data.

$$
\text { JoAN W. GoOdMan }
$$$$
\text { L. H. Sмiтн }
$$

Biology Division,

Oak Ridge National Laboratory

(Operated by Union Carbide Corporation

for the U.S. Atomic Energy Commission),

Oak Ridge, Tennessee. April 21.

'St. Amand, W., and Smith, L. H., J. App. Physiol., 14, 445 (1959).

${ }^{2}$ Smith, L. H., and Tohá, J., Proc. Soc. Exp. Biol. and Med., 98, 125 (1958).

${ }^{3}$ Gengozian, N., Makinodan, T., Congdon, C. C., and Owen, R. D., Proc. U.S. Nat. Acad. Sci., 44, 560 (1958).

\section{Assortative Mating and Reciprocal} Difference in the Blue-Snow Goose Complex

The lesser snow goose Chen hyperborea and the blue goose Chen caerulescens are maintained as good species by the standard taxonomic works ${ }^{1}$ though the morphological difference between them is confined to colour of plumage. The geographical distribution of the two is different. The snow goose ranges through Siberia, western Canada, the Hudson Bay area and Baffin Island; west of Banks Island the populations are unmixed. To the east, however, most populations contain some blue geese and in the Bowman Bay area of Baffin Island there exist several populations in which more than 90 per cent of the birds are blue. Where the populations are mixed, interbreeding between the two occurs, and the progeny produced are viable, fertile ${ }^{2}$ and phenotypically distinct ${ }^{3}$. This has led some authorities ${ }^{4}$ to consider the two forms to be polymorphs of one biological species. This communication is concerned with observations made by one of us (F. G. C.) on breeding behaviour in the mixed Boas River population, and for convenience the terms blue and snow are used in a purely descriptive sense. Table 1 shows the observed and expected (random mating) distribution for three

Table 1. OBSERVED AND Expected Distribution of DTFFerent MAtings IN A MIXED BLUE AND SNOW GoOSE POPULATION

\begin{tabular}{|l|c|c|c|c|}
\hline Type of mating & $\begin{array}{c}\text { Two snow } \\
\text { birds }\end{array}$ & $\begin{array}{c}\text { Two blue } \\
\text { birds }\end{array}$ & $\begin{array}{c}\text { One blue, } \\
\text { one snow }\end{array}$ & Total \\
\hline $\begin{array}{l}\text { No. observed } \\
\text { No. expected }\end{array}$ & $\begin{array}{l}373 \\
330 \cdot 4\end{array}$ & $\begin{array}{l}64 \\
21 \cdot 4\end{array}$ & $\begin{array}{c}83 \\
168 \cdot 2\end{array}$ & 520 \\
\hline
\end{tabular}

